\title{
THE EFFECT OF WEBSITE AND RELATIONSHIP MARKETING ON PURCHASE INTENTION THROUGH BRAND AWARENESS: CASE STUDIES ON RETAIL CUSTOMERS
}

\author{
Pradiani Theresia* \\ Institute of Economic Science Asia, Malang, Indonesia \\ Nirwanto Nazief, Subiyantoro Edi \\ University of Merdeka, Malang, Indonesia \\ *E-mail: thdiani12@gmail.com
}

\begin{abstract}
Indonesia is one of the countries in Asia Pacific with the largest e-commerce growth since 2017. Internet users have reached 63 million, about $95 \%$ of social media users. Website is one of the social media used by entrepreneurs for online marketing. Relationship Marketing is the company's strategy to attract purchase intention. MatahariMall.com is one of the $\mathrm{O} 2 \mathrm{O}$ based online retailers and provides 2000 Indonesian outlets. Relationship marketing and brand awareness arise in the minds of customers when registering members. Research aims at identify and find the variables that are estimated to build purchase intention customers transact online at MatahariMall.com customers in Malang area. The results showed that the website and relationship marketing has strong and significantly effect on purchase intention through brand awareness. The better quality system website and commitment in relationship marketing built retail website can increase brand awareness built retail website, reflected from brand recognition, customers will remember the retail website because the price of products sold on the retail website is known to be affordable and affect the purchase intention, which reflected in the intend indicators, customers will see the affordable price and quality of products so willing to follow the offer displayed on the retail website and interested buy, then, reflected from the predict indicators of customers, interested to become an active member in the near future.
\end{abstract}

\section{KEY WORDS}

Website, relationship marketing, brand awareness, purchase intention.

Online retailers grew exponentially in the last 10 years since 2000. Global online retailing increased $17 \%$ annually, in the last 5 years, from $\$ 236$ billion in 2007, to $\$ 521$ billion in 2012, estimated at \$1248.7 billion by 2017 (Verma, Sharma and Sheth, 2015). This fact is encouraging for online shopkeepers. By 2020, according to the E-Commerce Association of Indonesia, it is predicted that e-commerce market transactions in Indonesia will reach US $\$ 130$ billion (Rp 1,700 trillion), with annual growth of $50 \%$. Indonesia is one of the countries in Asia Pacific that has the largest e-commerce growth until 2017. Online shopping / e-commerce trends become the company's choice to run marketing activities (idEA, 2017).

Ganguly et al (2010), revealed the phenomenon of internet marketing world is increasing, proven many people who transacted buying and selling through the internet. Jupiter Corporation USA (2010) confirmed the sale and purchase transaction in USA in 2010 reached $\$ 144$ billion. The development of the Internet also penetrates the country that has a growing economic condition, developing, and entering a transition period such as ASIA. Grabner et al (2003) proves the key to online business is to build consumer confidence. Social media is a means that gives a real ease of communicating even if not face-to-face. Consumers can do a wide variety on social media, for example: searching for product information, comparing other products, to online purchases. This has an impact on companies that start using social media for business purposes, in increasing awareness, 
engagement to consumers, and selling online. Purchase Intention online shopping customers woke up, because emerging brand awareness, after viewing the website displayed, companies need to build brand awareness by creating a relationship marketing strategy.

Building brand awareness and customer relationship marketing with the company needs to make various changes, in accordance with the development of information technology, so that the main objectives are achieved and win the competition. Relationship marketing today, as a valuable of marketing strategy for the company. Relationship marketing will produce greater productivity, specifically build brand awareness. Companies that focus on relationship marketing, have significant differences in sales volume and brand, compared to companies that are not focused. The concept of relationship marketing consists of components of behavior such as trust, commitment, and satisfaction, as the company's assets achieve a competitive advantage (Ghani, 2012). The more companies take advantage of relationship marketing with customers, will gain valuable information on how best to serve customers and prevent customers from switching to competing brands, as well as materials for strategizing marketing planning. Therefore, companies need to build customer relationships creating mutually beneficial rewards (Jesri et al., 2013).

Business can win the competition, if the company is able to build purchase intention customers to buy the product. When consumers want to buy a product, the brand name instantly comes to mind, it reflects the product has a high brand awareness. The cost to attract new customers, five times greater than the cost of retaining customers. The higher the customer knows the brand, the lower the business cost incurred (Chi et al, 2009). Relationship Marketing is strongly associated with trust, communication, and commitment to build consumer purchase intention, this supports trust commitment theory Morgan and Hunt (1994) which mentions the success of Relationship Marketing is built from relationship commitment and trust, together encourage marketers to work together to maintain relationships investment with partners. Gholami (2017) concludes, how the process of quality factor relations (trust, satisfaction, and commitment) translate into brand equity results, proven trust, customer satisfaction, and commitment positively impacts brand equity, and brand awareness as a mediator, significant between brand equity and relationship commitment.

Brand trust and brand attachment have a positive effect on purchase intention. This is supported by Yogesh and Yesha (2014) that, social media is most widely used as a source of information for convenience, effectiveness and credibility. Social media reviews and opinions also affect purchase intention and purchasing decision processes. Online retailers can increase the chances of retaining customers by focusing on relational. The findings in this study highlight several factors related to the important relationships that online retailers can retain customers (Mpinganjira, 2014). Online advertising activity positively affects the frequency of customer purchases, high awareness of online activity is also positively correlated with customer purchase intention (Blaga, 2015).

Ad design, content and size define purchase intention. The more specific, the better the design and the more detailed the content of the ad and the larger the ad size, the greater the likelihood that the respondent will buy the product. Convenience also affects the purchase intention of respondents (Anh and Tuan, 2016). Online shop is a purchase through the internet as a marketing medium, using the website as a catalog (Oliver and Anja, 2008). The interactive nature of the internet offers the opportunity for consumers to use web shopping facilities effectively by improving the availability of product information, enabling direct attribute comparison, and reducing the cost of searching for potential buyer information (Alba et al., 1997).

Web Online shop displays a variety of products and services that have its own appeal why many visited. This is supported by Kotler and Keller (2003: 186) that consumers have the desire to buy products based on the brand. Chandon and Muller (2003) concluded, that the development of electronic technology has increased consumer exposure to websites and digital brands. Currently, much attention is devoted to examining the effects of websites on price sensitivity, shopping behavior or satisfaction. Some studies alone try to emphasize the effect of the website on the actual brand image. The Internet, representing a new channel of 
communication and distribution for brands, offers a new context for offline brands, which may have positive or negative effects for brand image.

Brand image can be built well if the website used internet advertising media to give attention of a mediation and communication from sources identified, to be given to consumer in taking decision now and future. More than that, it is very appropriate if internet advertising is defined form of communication in accordance with the definition of advertising obtained on the internet (Millan, 2004). The quality of website design as an advertising medium has an important role to attract consumers online shopping (Ganguly et al, 2010). The level of customer satisfaction of e-commerce is closely related to the quality of website design (Cho and Park, 2001). Ranganathan and Grandon (2002) convey website design describes the condition and situation of the company. When consumers shop online Shop, consumers do face-to-face techniques with the Internet without exertion. Website design is able to move consumers to take action face to face and play a role in influencing consumers (Wolfinharger and Gilly, 2003).

Lee and Lin (2005) found that overall website design had a positive influence in shaping the level of customer satisfaction and service quality. In contrast to Besider et al (2002) which proves, website design has a positive effect on purchase intention. This is also stated by Chang dkk (2014) who argued that, website quality is the key factor of electronic commerce, because customer perception about website quality positively affect the interest of customers using the site and directly affect purchase intention. The scale of measuring website quality is, quality of information, system quality, service quality. Purchase intention of consumers arise because of brand awareness owned.

Brand awareness is a powerful strategy for influencing consumer purchase intention. When consumers choose and estimate the product, brand awareness has an important role, in the process of promoting and marketing the product. Companies use brand strategy as the primary focus for increasing market share effectively, by building consumer brand loyalty to build a strong image (Chang and Chang, 2014). Chou and Lien (2011) convey that, brand awareness of consumer main consideration. Brand awareness is important when consumers make purchasing decisions of foreign products: well-known brands (high popularity) are most likely to have positive feedback from consumers rather than anonymous (low popularity). Brand awareness by Hsieh and Chen (2011) enables consumers to easily recognize and deliver high-awareness product values, referred to consumers associating with a particular brand name when thinking about a particular product. A brand that is easy to remember according to Berry (2000) can create brand awareness products to consumers. One of the benefits of building website brand awareness. Attractive websites create issues that circulate quickly in cyberspace and real, and make people aware of brand presence, and increasingly curious and want to find out the product, resulting in the decision to consume products (Gensler et al, 2013).

The research gap found, Chianasta and Wijaya (2014) found, marketing promotion using social media Leonovo products in Indonesia did not have a positive impact. Ganguly et al (2010) is also mentioned different, first high consumer purchase intention when the website design of advertising media, offering lower prices and can build consumer confidence; second, the website contains cultural values will affect purchase intention. In contrast to findings from Siddique and Rashidi (2015) that, social networking is negatively related to brand awareness while blogs and media sharing are positively related. Hasanov and Khalid (2015) also stated that, website quality is not a decisive factor in increasing consumer purchase intention. Based on the difference of research result before, spur to deepen and do research about website and relationship marketing influence to purchase intention through brand awareness.

\section{LITERATURE REVIEW}

The results of Srinivasan et al (2016) study were used as a reference for social media marketing strategies for Micro Small and Medium Enterprises (MSMEs) for customer acquisition and retention. As they demonstrate that social media participation strongly 
influences brand awareness, which ultimately increases market share. Barreda et al (2015) also proved, the extraordinary interactive and communicative capabilities of OSN (Online social network), was found as a valuable pioneer in building brand awareness. Alhaddad (2015) found Advertising Awareness has a significant positive impact on brand awareness, brand image and brand equity. Ukkwatte and Abeysekera (2015) found that hotel customers, proves relationship marketing is positively associated to brand equity. The results of qualitative analysis are found, consumers and being more confident and committed to the hotel because of relationship marketing. This is also being motivated to spread the good news to others and return to the hotel so that leads to the strengthening of brand equity. The results of relationship marketing have a positive impact on brand equity.

Kim and Ko (2010) also conducted research on the impact of clothing brand on marketing in social media on relationship marketing and purchase intention. The results show that managing relationship marketing on trust significantly improves purchase intention. Only trust in relationship marketing is significantly related to purchase intention. This is supported by Verma, Sharma and Sheth (2015) that identify specifically, the main thing that affects the relationship marketing and the consequences of relationship marketing in online retailing. The results show that relationship marketing is very important, so as not to switch to other sites. Trust is considered the determinant of success in online retailing. The main thing that drives relationship marketing, customer focus, motivation provides flexibility in spending time, reduced spending time, and sparingly, as it spares from unexpected buying (impulse buying). Trust is stronger in relation to expectations of continuity of purchase (expectation of continuity). The expectation of continuity is the intention of the customer to maintain the relationship in the future, with purchase intention, trust as an indicator of relationship marketing (Morgan and Hunt, 1994) strongly encourage purchase intention.

Yaseen et al (2011) also found in a study for 200 resellers that, the impact of brand awareness and loyalty was not significant, a significant impact of perceived quality on profitability. The conclusion is, brand awareness, perceptions of quality and loyalty have a significant impact on purchase intention. This is supported by previous research by Chang dkk (2014) to hotel customers, that purchase intention is positively influenced by the trust and quality of the website. The dimensions of website quality are system quality, service quality and information quality. Based on the difference of research result before, spur to deepen and do research about website and relationship marketing influence to purchase intention through brand awareness.

Purchase intention is still being used as a vital concept in marketing (Morrison, 1979). Purchase intention is a consumer plan to make an effort to buy a particular brand or product (Spears and Singh, 2004). The brand name has become the right tool for multinational companies as standardization to gain positive market share and benefit globally, examples of global brands such as Procter and Gamble, Unilever, Nestle, Prada, Rolex, McDonalds and Coca Cola (Smith and Brynjolfson 2001). In modern times, brands have an important role to improve the country's economy. Global brands help national governments to improve shortterm liquidity and finance short-term projects. A brand is a tool used by marketers to change consumer purchase intention. Today, consumers are more familiar with brands (Shehzad et al., 2014).

For years the evolution of the internet as a marketing medium has become a global phenomenon, leading to the rapid escalation of e-commerce in the last decade (Ganguly et al, 2010). Social media became the modus operandi of the 21st century. Building on the foundation of Web 2.0, social media applications have facilitated the growth of unprecedented human interaction in modern times (Balakrishnan et al, 2014). Many studies have proved that perceived customer confidence is the fundamental determinant in business transactions (Chu, 2009). This is an important step in building long-term relationships between buyers and sellers (Sirdeshmukh, 2002). With respect to the internet and ebusiness, increasing trust for customers is very important, without trust, customers will not be shopping online (Kim et al, 2008). In this study using several theoretical basis below.

Purchase intention. Consumer intention Purchase is a consumer behavior that has a desire in buying or choosing a product, based on experience in choosing, using and 
consuming or even wanting the product. Consumer intention buying is something that arises after receiving the stimulus from the product it sees, from there arises interest to try the product until finally arises the desire to buy in order to have it (Kotler, 2005). Purchase intention indicates that consumers will follow the experience, preferences and external environment to gather information, evaluate alternatives, and make decisions. The indicators of purchase intention are explained by the following components: Schiffman and Kanuk (2007: 470), interested in finding information about the product, considering buying, interested in trying, wanting to know the product, wanting to have the product. Till and Busler (2000), purchase intention is measured through the likely dimension of a consumer purchase plan for a product. Based on Pavlou's (2003) argument, online purchase intention is a situation where the customer is willing and intend to engage in online transactions. Online transactions can be regarded as activities where the process of information retrieval, information transfer, and product purchase is done. The search and exchange of information is considered an interest in using the website; However, the purchase of the product is more in line with the interest to handle the website. Traditional retailers face huge challenges, a phenomenon today many young people are switching to online shopping (Krbová and Pavelek, 2015). Lifestyle changes show the current trend. Business communications have changed, and traditional businesses need to adjust and accommodate these changes. The world is now surrounded by high technology; Therefore businesspeople must adjust and understand how social network marketing can impact consumer purchase intention (Tor et al., 2017).

Yaseen et al (2011) said that brand awareness, perceived quality, and loyalty have an effect on purchase intention (purchase intention). Thus, it can be understood that the definition of purchase intention is a tendency to feel interested in getting activities and have goods and services. In general, people buy something is preceded by the purchase intention of the person against the goods to be purchased. The purchase intention indicator used in Ling, Chai and Piew (2010) research, is described in the following question, I will probably trade with this web retail in the near future, considering the opportunity, I intend to use this retail website, and I predict that I should use this retail website in the future. The result is that interest in impulse buying, quality orientation, brand orientation, online trust and online purchases of past experiences are positively related to online customer purchasing interest. Research conducted by Hausman (2009) indicator used is definitly, intend, likely and expect.

Brand Awareness. Brand (brand) is a product or service that has differences in certain dimensions, which distinguishes from other products or services designed to meet the same needs. These differences may be functional, rational, or directly related to the product performance of the brand. Differences may be more symbolic, emotional, or intangible related to what the brand represents or more abstract (Kotler and Keller, 2012: 241). There are two brands in Brand: Brand Equity and Brand development, Brand Equity Sub-Brand, Brand Awareness and Brand Perceived Quality, and Brand Brand is Brand Image and Perceived Quality. This research focuses on brand awareness (Brand Awareness). Brand awareness has a high correlation with the intensity of purchases, market share and other important brand equity, as well as business matrices. If the company has created a superior product and has a price and delivered a very good value, but product support has bad service, and no one has ever known the product, then the company has trouble selling the product. Brand awareness is very important. due to the strong brand base, as well as an important component of brand equity. The first step to building brand equity is brand awareness (Aaker, 2004).

Brand awareness is the ability of consumers to identify brands in diverse conditions (Keller, 2008: 51). Brand awareness is closely linked to brand power in the minds of consumers, which can be measured through the ability of consumers to identify brands in varying circumstances, namely, unaware of brand, recognition, brand recall, top of the mind brand (Aaker 1991: 62). Unaware of Brand is the lowest level in the pyramid of brand awareness, where consumers are not aware of a brand that is done with the help of recall (aided recall). Brand recognition is the measurement of brand awareness of respondents, where the awareness is measured by the help of questions asked assisted by mentioning the 
characteristics of the brand product (aided question). Questions are asked to find out how many respondents need to be reminded of the existence of the brand. Brand recognition is a minimal level of brand awareness, with brand recognition reappearing after reassignment. Brand Recall is an unaided recall, or a brand reminder reflects what brands the respondent remembers after mentioning the first-mentioned brand. Top of Mind is the peak of mind that first appeared in the minds of consumers and was first mentioned by consumers.

Website. Website part of social media development and Web design that is the second generation, aims to facilitate communication, provide security of various kinds of information, interoperability and collaboration on the World Wide Web. "(Kaplan and Haenlein (2010) describe social media as a group of Internet-based applications built on the foundation of ideology and Web 2.0 technology, and which provides the possibility of user-generated content creation and exchange Web 2.0 technology on Social Web allows two-way conversations with consumers, enables brands to listen to consumers and respond (Fournier and Avery , 2011) .Consumers and organizations alike are increasingly using the web to discuss, share, and collaborate (Jones, 2010).

Ahn, Ryu and Han, (2007) found that Web quality, categorized in system quality, information quality, and service quality, had a significant impact on perceived ease of use, love of online retail users, and resulted in, encouraging the use of websites in context online retail. Website quality is a key factor in e-commerce, because customer perceptions of website quality positively impact their intention to use the site (Chang and Chen, 2008), and directly affect purchase intention (Knight, Choudhury and Kacmar, 2002). Website quality is a multi dimensional construction consisting of information quality, system quality, and service quality Chang et al (2014). According to Lin (2007), the scale of the three dimensional site quality model used is, Information and system quality is defined from a technical point of view, the quality of service from a customer-oriented perspective. Online advertising by Smith (2008), online web shop form of online advertising on social networking sites such as facebook world divided into 6 categories ad website, page ad, house ad, evented ad. Gift ad and video ad.

Relationship Marketing. Morgan and Hunt (1994) define Relationship Marketing in terms of trust and commitment. To develop long-term customer relationships, organizations must win the trust of customers, for which customer commitment to the organization must increase. This is done by keeping each other's promises. Morgan and Hunt (1994: 23) convey also that, the concept of trust arises, when one party has trust in the other side in terms of integrity and reliability. The extent to which partners can trust each other, understand the importance of the power of relationship marketing. Commitment as an exchange partner who believes that ongoing relationships with others is vital to assure maximum effort in defending it, that is, committed parties believe the relationship is worth doing to ensure it will last forever. When the organization is able to win the trust of the customer, the customer's commitment to the organization will simultaneously increase, so that the relationship between customer and organization will be established. Therefore, trust and commitment are regarded as two key principles in relationship marketing. In relationship marketing, satisfaction is important because, high relationship satisfaction can reduce the intensity of blame and unstable emotions in an unharmonious relationship (Caceres and Paparoidamis, 2007). In addition, relationship satisfaction also affects the company's performance both objective and subjective performance. For example, in the context of a buyer's relationship with the seller. Stock (2005) found that, there is an inverse relationship between satisfaction and objective performance measurement that refers to price sensitivity, the higher the level of customer satisfaction, the lower the sensitivity of consumer prices.

According to Ghani (2012) satisfaction is defined as an evaluation of the overall feelings resulting from specific exchange and acceptance relationships, considerations and feedback, and implementation of strategies based on any market information from the various parties involved. Ukkwatte and Abeysekera (2015) also convey that relationship marketing has a positive value impact on brand equity. Furthermore, this research can be considered important in order to prioritize strategies to achieve sustainability of competitive advantage. The concept and practice of relationship marketing marketing is useful in building 
strong relationships with online retail customers (Bendapudi and Berry, 1997). The concept of relationship marketing has been useful in the development of definitions of new concepts such as trust, commitment, closeness and quality of relationships (Morgan and Hunt, 1994).

\section{CONCEPTUAL FRAMEWORK AND HYPOTHESES}

Chi, Yeh, Chien, and Yang (2009) research on cellular users and proven, brand awareness, perceived quality and brand loyalty to purchase intention have a positive and significant impact, and then the perceived quality of the user positively impacts brand loyalty, and the quality perceived users, and will mediate between the effects of brand awareness and purchase intention, and brand loyalty will mediate the influence between brand awareness and purchase intention. Ling, Chai and Piew (2010) findings suggest that impulse purchase intention, quality orientation, brand orientation, trust online and online purchases of past experience are positively associated with online customer purchase intention. This is also conveyed by Yaseen et al (2011), that from the point of view of retailers, brand awareness (brand awareness), perceived quality and loyalty affect consumer purchase intention. Research on airline passengers in China, (Choe and Zhao, 2013) results in that brand equity directly affects purchase intention; transition costs directly affect brand equity; and transition costs indirectly affect purchase intention. Brand marketing strategies, can be more effective for certain customer groups, including high-income customers, married, government employees, and employers.

When a person decides to run a business both offline and online, what he thinks is success. The success and recognition of the most important business brand while creating a business plan. Social media play a role to promote the brand, organize and market worldwide. The world is full of new things, media and digital communication technologies. The impact of promotion through social media is enormous and gives a combination of speed and relevance. Brand awareness of important factors increases the company's product sales ratio. The results of Arora and Sharna (2013) proved, social media the best tool in building brand awareness. Alhaddad (2015) conveyed internet advertising containing advertising awareness influential brand awareness and brand image, and impact on brand equity. Internet advertising consists of, I remember seeing an advertisement for this type of brand on social media, and social media is full of ads for this type of brand. Variable item for brand awareness is, I am aware of this brand, I can recognize this brand among the competing brands, I know what this brand is like.

Barreda (2015) supports important social media (Online Social Networks / OSNs) which is an extension of the website brand, in an online branding strategy. virtual interactivity, system quality, information content quality, and activity, are beneficial to influence and generate brand awareness and trigger WOM (world of mouth). Al-Fawwaz et al (2015) found a significant positive relationship between brand awareness and Ecommerce sales. Srinivasan et al (2016) convey the participation of social media has a strong influence on brand awareness. The role of social media to build brand awareness is closely linked. The fastest growing media ad for advertising is the Internet. The current development, concerns of large populations are busy using the internet and websites. Godey et al (2016) conducted research on how social media marketing activities affect the creation of brand equity and consumer behavior toward brands. Research explores this relationship by analyzing the luxurious perfume brands (Burberry, Dior, Gucci, Hermès, and Louis Vuitton). The survey of 845 consumers in 4 countries (China, France, India, and Italy), which uses five brands studied in social media, found social media to have a significant positive effect on brand equity and on two major dimensions of brand equity: brand awareness (brand awareness) and brand image.

Vennila and Mekala (2017) also said that online marketing has a role to play in building big brands and companies known to the public. One way to increase online brand awareness through marketing channels. Relationship marketing emerges as the strongest marketing tool to grow customer loyalty, interaction and long-term engagement. Today in a day, companies throughout the industry rely on relationship marketing to expand market share, by 
strengthening customer relationships (Gaurav, 2016). Ghani (2012), found in Malaysia, the relationship of car dealerships adopts moderate relationship marketing with high among each dealer with the company. This relationship, there is a difference between the relationship marketing component with the four car sales dealers against the company brand. The findings tend to show that relationship marketing is an important factor in proposing why a particular brand's sales volume is higher than others. Great attention to relationship marketing will create a significant difference in the company's brand sales. Verma, Sharma and Sheth (2015) said that building relationship marketing is important, because customers are not easy to switch to other sites. Trust is an important determinant of success in online retailing. Specifically the thing that drives relationship marketing to customer focus, which is the motivation to provide flexibility of shopping time, reduced spending time, and sparingly due to avoidance of unexpected buying (impulse buying). Trust is stronger in relation to expectations of continuity of purchase (expectation of continuity). The expectation of continuity is the intention of the customer to maintain a future relationship with an interest in buying. Continuity of purchase (expectation of continuity), is a very detailed concept where empirically, (expectation of continuity) uses various constructs similar to purchase intention. Trust as an indicator of relationship marketing (Morgan and Hunt, 1994) strongly encourages purchase intention or spending interest.

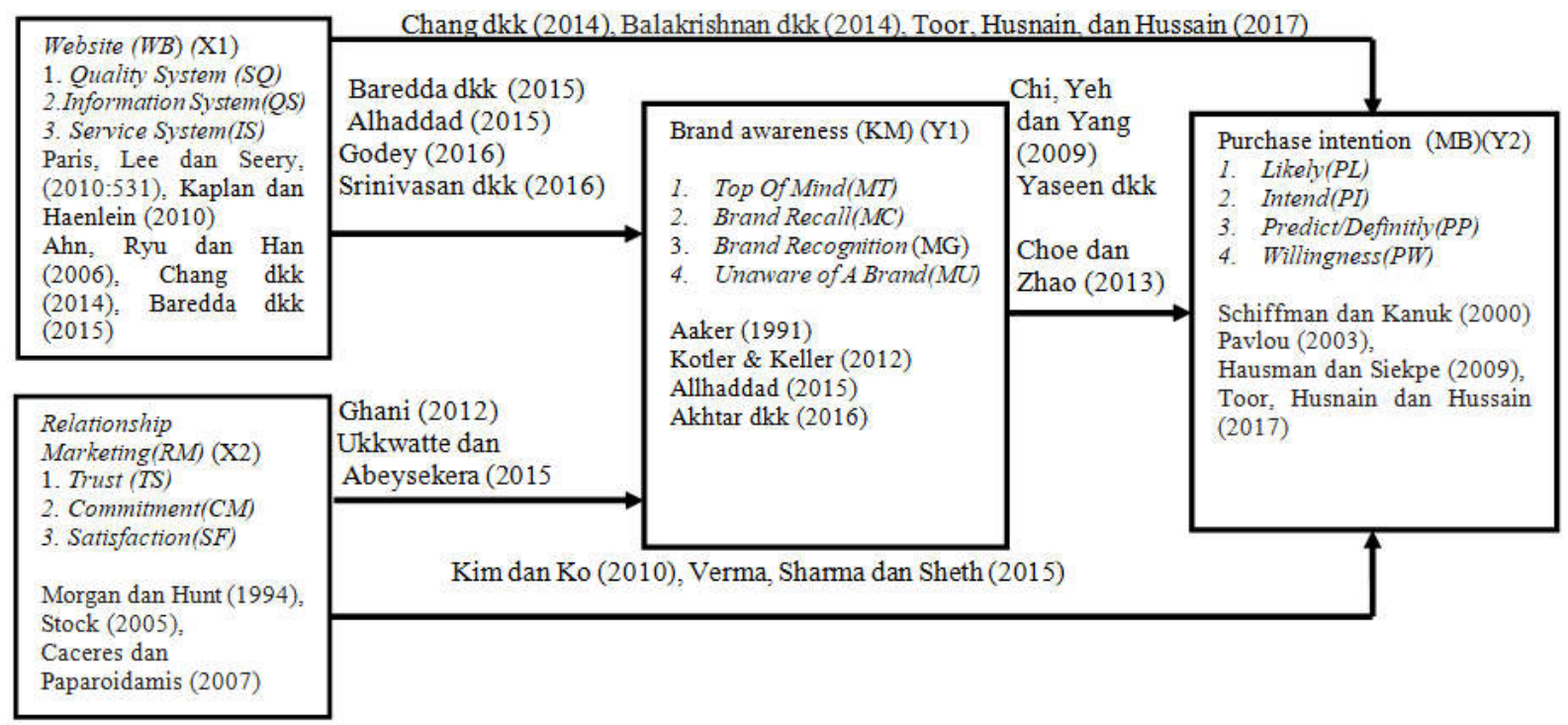

Figure 1 - Research Model

Clothes marketing in social media affects relationship marketing and purchase intention (Kim and Ko, 2010) managing customer relationships on trust significantly improves purchase intention, only trust in customer relationships is significantly related to purchase intention. Purchase intention is also affected by website design (Ganguly et al, 2010), website design can positively affect purchase intention, and reduce perceived risk. Variable website design items are information design, visual design and navigation design. The question variable variable for purchase intention is, I am interested in continuing to use an online store to buy products or services in the future, I would strongly advise others to use the online store that I use, and I can not transact with online stores any time soon. Websites that support online sales have gained significant popularity. Website engagement is positively related to attitudes toward the website, which ultimately affects consumers' desire to buy on the website (Jiang et al, 2010) Category of websites used, interactivity and invovement, variable items from purchase intention, likely, possibly, certain and definitely. Balakrishnan (2014) proves online advertising has a positive impact on brand loyalty and purchase intention in generation Y. Nikhashemil et al (2013) convey the same thing that is, web-based advertising (E-Advertisement) affect consumer purchase intention. The progress 
of the World Wide Web has created a new form of retail transaction in electronic retail/eretailing, so customer involvement in online transactions is important.

Based on the research model generate the following hypothesis:

Hypotheses:

H1: Website and Relationship Marketing have a significant effect on brand awareness on retail website customer of Malang Raya area.

H2: Website and Relationship Marketing have significant effect to purchase intention on retail website customer of Malang area.

H3: Brand awareness significantly affects purchase intention on retail website customer of Malang area.

H4: Website and Relationship Marketing have significant effect to purchase intention with brand awareness as mediator to retail website customer of Malang Raya area.

\section{RESULTS AND DISCUSSION}

Model Conformity Test (Goodness of Fit). In accordance with the literature review and research objectives, an overall structural model was developed. Based on AMOS 22 computations, the SEM model is generated by a goodness of fit index, presented in Table 1. Next, the index values are compared to the cut-of values of each index. A good model is expected to have goodness of fit indices greater than or equal to the critical value. The results of the evaluation of Goodness of Fit Indices criteria indicate that the overall model evaluation has met, the model is acceptable.

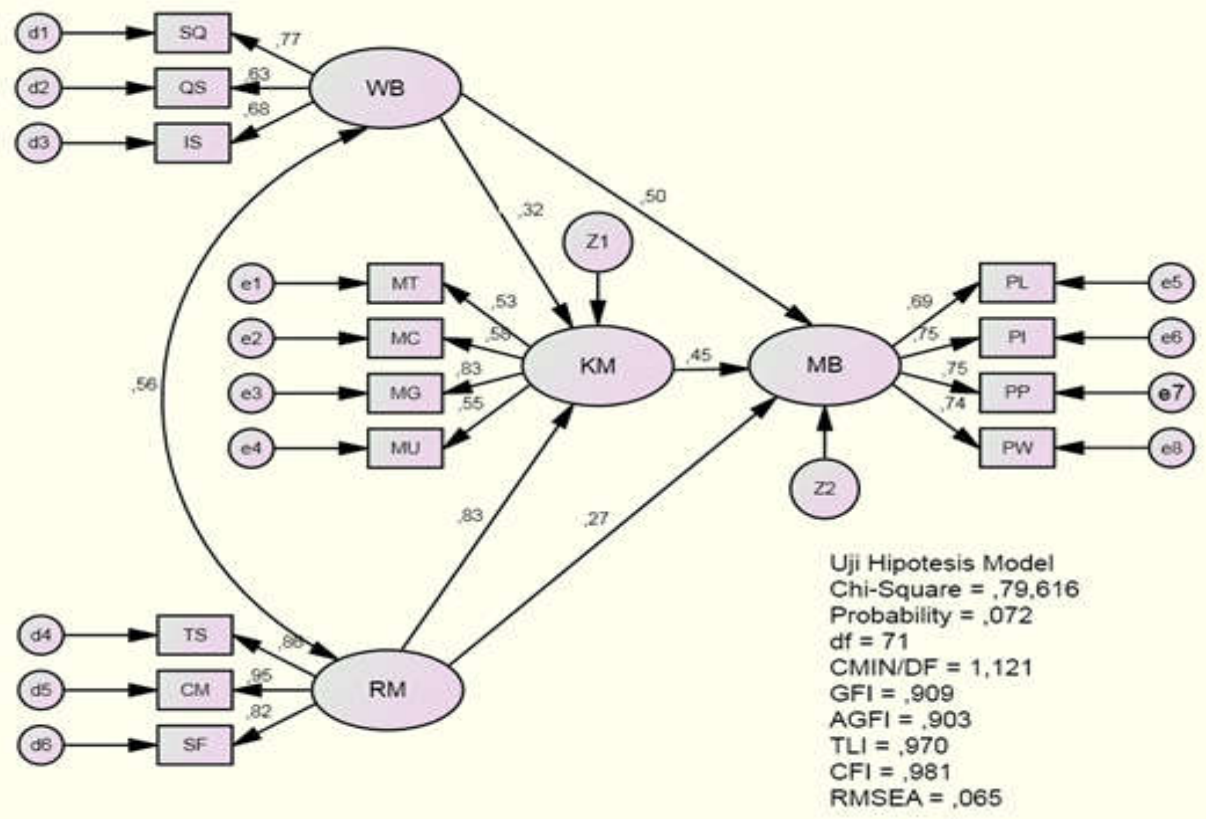

Source: Primary data Processed 2018.

Figure 1 - Results of SEM Analysis

The result of SEM analysis in Figure 1 is explained as follows: website variables affecting purchase intention that is, quality system has the biggest contribution that is 0.77 reflected from MatahariMall.com website respond to customer transaction process, followed by information system equal to 0.68 and service quality 0,63 . Relationship Marketing SEM test results show that the largest contribution to affect purchase intention, is a commitment of 0.95, reflected from the website MatahariMall.com commitment to receive input from customers, followed by trust of 0.86 and satisfaction of 0.82 . Brand awareness as the intervening variable of the website and relationship affects the purchase intention, which has the greatest contribution, the brand recognition of 0.83 is reflected from the customers know 
MatahariMall.com because it has affordable products, followed by recall bronze 0.58 , unaware off brand 0,55 and top off mind 0,53. Purchase intention of SEM test result which has the largest contribution of purchase intention intend and predict, each of 0.75 , is reflected from the customer plan will follow the offer and consider online shopping, after seeing the product quality and affordable price in MatahariMall.com website, and customer in the near future will be an active member and buy products online, then followed by the willingness of 0.74 and likely 69 .

Table 1 - Test Results of Goodness Of Fit Modified Structural Models

\begin{tabular}{|c|c|c|c|}
\hline Goodness Of Fit Index & Cut-of Value & Results Model & Description \\
\hline Chi-Square $(\mathrm{df}=71)$ & 91,670 & 79,616 & Good \\
\hline Probability Chi-Square & $\geq 0,05$ & 0,072 & Good \\
\hline CMIN/DF & $\leq 2,00$ & 1,424 & Good \\
\hline RMSEA & $\leq 0,08$ & 0,014 & Good \\
\hline GFI & $\geq 0,90$ & 0,909 & Good \\
\hline AGFI & $\geq 0,90$ & 0,903 & Good \\
\hline TLI & $\geq 0,95$ & 0,970 & Good \\
\hline $\mathrm{CFI}$ & $\geq 0,95$ & 0,981 & Good \\
\hline
\end{tabular}

Source: Primary Data Processed 2018.

In Table 2, all variables have a value $P$ (Probabilita) smaller or equal to 0.05 , then it can be said to have a significant influence. All variables have a criticical ratio (CR) greater than 2. In Table 3 it is shown that the total effect value of $(0.647)$ is greater than the direct effect $(0,505)$ and the total influence value of $(0.644)$ is greater than the direct effect $(0.274)$, so the first hypothesis $(\mathrm{H} 1)$, second $(\mathrm{H} 2)$, third $(\mathrm{H} 3)$ and fourth $(\mathrm{H} 4)$ are statistically tested.

Table 2 - Influence of Website and Relationship Marketing to Brand Awareness and Purchase Intention

\begin{tabular}{|c|c|c|c|c|c|c|}
\hline \multicolumn{2}{|c|}{ Variabel } & Standardized Regression Weight & Estimate & S.E. & C.R. & $\mathrm{P}$ \\
\hline Website & Brand Awareness & 0,320 & 0,727 & 0,239 & 3,037 & 0,002 \\
\hline Relationship marketing & Brand Awareness & 0,831 & 0,729 & 0,087 & 8,408 & 0,000 \\
\hline Website & Purchase Intention & 0,505 & 0,937 & 0,193 & 0,859 & 0,000 \\
\hline Relationship marketing & Purchase Intention & 0,274 & 0,196 & 0,082 & 2,384 & 0,017 \\
\hline Brand Awareness & Purchase Intention & 0,445 & 0,363 & 0,086 & 4,211 & 0,000 \\
\hline
\end{tabular}

Source: Primary Data Processed 2018.

Table 3 - Influence of Website and Relationship Marketing Against Purchase Intention through Brand Awareness

\begin{tabular}{|c|c|c|c|}
\hline Variable & Direct Influence & Indirect Influence & $\begin{array}{c}\text { Total } \\
\text { Influence }\end{array}$ \\
\hline Website terhadap Purchase Intention melalui Brand Awareness & 0,505 & $\begin{array}{c}0,320 \times 0,445= \\
0,142\end{array}$ & 0,647 \\
\hline $\begin{array}{c}\text { Relationship marketing terhadap Purchase Intention melalui Brand } \\
\text { Awareness }\end{array}$ & 0,274 & $\begin{array}{c}0,831 \times 0,445= \\
0,370\end{array}$ & 0,644 \\
\hline
\end{tabular}

Source: Primary Data Processed 2018.

\section{CONCLUSION AND SUGGESTIONS}

Websites and relationship marketing affect brand awareness on retail website customers. Quality system of retail website that display product design according to customer requirement and respond to customer transaction process, along with relationship marketing built with commitment to receive input from customer and solve customer problem, can build brand awareness of customer with brand recognition, because retail website is known to display product goods at an affordable price. The results of the research are consistent with Baredda et al (2015), Alhaddad (2015), Godey (2016) and Srinivasan et al (2016) which states the website has an effect on brand awareness. Relationship marketing affects brand awareness, which means that increased relationship marketing can increase 
brand awareness. The results of this study are consistent with Ghani (2012) as well as Ukkwatte and Abeysekera (2015).

Websites and relationship marketing affect purchase intention on retail wesbite customers. Quality system of retail website showing product design according to customer requirement and responding customer transaction process, along with relationship marketing which is built with commitment to receive input from customer and solve customer problem, influence to purchase intention in intend and predict customer, that is after seeing product price an affordable customer considers buying, and after looking at the quality of the product, the customer is willing to follow the offer submitted by the retail website, then the customer predicts will be an active member and interested in online shopping in the near future on the retail website. The results of this study are consistent with Chang et al (2014), Balakrishnan et al (2014) and Toor, Husnain, and Hussain (2017), which states that the website affects purchase intention. Relationship marketing has an effect on purchase intention, the result of this research is consistent with Kim and Ko (2010) and Verma et al. (2015).

Brand awareness of customers formed from brand recognition, showing that retail websites are known to display goods products at affordable prices affect purchase intention affect customers in intend and predict customers, that is after seeing the price of affordable products customers consider to buy, and after seeing the quality of the product, the customer is willing to follow the offer submitted by the retail website, then the customer predicts will be an active member and interested in buying in the near future on the retail website, meaning that the increase in brand awareness can increase purchase intention. The results of this study are consistent with Chi et al. (2009), Yaseen et al (2011) and Choe \& Zhao (2013).

Brand awareness in this brand recognition is a website known to display goods products at affordable prices, it is already formed in the minds of customers, mediate the influence of the website that prioritizes the quality of the system by displaying product design according to customer needs and respond to customer transaction process, also mediate relationship marketing, the company is committed to receiving suggestions and feedbacks as well as resolving customer issues thereby making customers comfortable. affect the purchase intention, in this case the customer is interested to follow (intend) bidding done retail website, after seeing the quality of the product and consider shopping online after seeing the price of the product, in addition the customer predict (predict) will be an active member and interested in buying in soon.

This research for the development of science in the hope can enrich the marketing concept, especially internet marketing, relationship marketing, brand awareness and purchase intention to be applied in retail marketing. For online companies, the quality of the website, always updating the content and the website design more attractive so as to increase customer purchase intention, such as the addition of features, payment method facilities, more detailed information and easy to understand, adding to the language vocabulary, product location information is clear, not just on special and important days, adding content about news or tips related to the product being sold, eg tips on how to care for clothing based on the type of cloth, giving greeting on special days commemorated by the customers, regular interesting promos through account customer-owned social media, product-variatif, type and price competitive, so that customers do not move to another marketplace, the addition of outlets on the location can be reached by the community. Companies in Relationship marketing, need to build a community by utilizing the latest information technology that can be accessed globally as a container for mutual communication and sharing for customers, to solidify customer relationships with companies that benefit both parties. For the following research, it is expected to develop the current research, by adding repurchase, customer loyalty and customer satisfaction, population variation and number of samples with addition of criteria and using or adding technical data analysis different from this research to be more complete, and findings obtained more leverage. 


\section{REFERENCES}

1. Vennila and A Mekala, 2017. Internet marketing to improve brand awareness. International Journal of Commerce and Management Research, 2455-1627.

2. Abzari, Mehdi, Reza A. Ghassemi, and Leila N. Vosta. 2014. Analysing The Effect of Social Media on Brand Attitude and Purchase Intention: The Case oflran Khodro Company. Journal of Social and Behavioral Sciences, Vol. 143, No. 71, (822-826).

3. Aaker, D, (1993). " Apakah investasi ekuitas merek benar-benar berharga ", di Aaker DA and Biel, A. (Eds), Brand Equity and Periklanan; Peran Periklanan dalam Membangun Merek Kuat, Erlbaum, Hillsdale, NJ, pp. 333-41.

4. Aaker, D.A., Kumar, V., Leone, P.R.,Day,s.g., 2013. Marketing Research, Willey, Singapore.

5. Aaker, D.A., 1991. Managing Brand Equity, Capitalizing On The Value Of The Value Of A Brand Name, New York, The Free Press. P.150

6. Alba, J. W., and Chattopadhyay, A. (1986). Salience effects in brand recall. Journal of Marketing Research, 23(4), 363-369.

7. Assael, Henry. (1992). Consumer Behavior and Marketing Action, 4th ed. Boston.

8. Ahn, Tony, Seewon Ryu, and Ingoo Han, 2007. The Impact of Web quality and Playfulness on user acceptance of online retailing. Journal of Information and Management of Elsevier, 263-275.

9. Akhtar, Naeem, ljaz Ahmed, Hafiza Yasmeen Jafar, Ali Rizwan, and Junaid Mohsan Nawaz, 2016. International Review of Management and Business Research, 23069007.

10. Alhaddad, Abdullah Awad, 2015. The Effect of Advertising Awareness on Branding Equity in Social Media. International Journal of e-Education, e-Business, eManagement, and e-Learning,73-84.

11. Aqsa, Muhammad and Dwi Kartini, 2015. Impact of Online Advertising on Consumer Attitudes and Interests Buy Online (Survey on Students of Internet Users in Makassar). International Journal of Scientific and Technology Research Volume 4, Issue, 04 22778616.

12. Arora, Shruti, Anukrati Sharma, 2013. Social Media: A Successful Tool of Brand Awareness, International Journal of Business and General Manager, 2319-2267

13. Assael, Hendri, 1984. Consumer Behavior and Marketing Action, 2 nd edition, Kent Publishing Caompany, Boston

14. Augusty Ferdinand, 2006, Metode Penelitian Manajemen, Baand Penerbit Universitas Diponegoro, Semarang, 12.

15. Anh T.P., Tuan V. Q., 2016, Determinan of Social Media Influence on Consumer's Purchasing Intentions: The Case of Facebook in Vietnam, International Journal of Economics, Commerce and Management United Kingdon, Vol. IV, Issue 7, Jully, ISSN 2348 0386, http://ijecm.co.uk/, p. 432-442.

Al-Fawwaz B.M., Al-Shatnawi A.M, Alsharafat W.S., 2015, Recognizing The Importansce of Brand Awareness on E-Commerce Sales While Shopping on Internet: Empiricical Analysisi of European Countries, iJIM, Volume 9, Issue 1, http://www.ijim.org. P. 15-18.

Adamu U. G. and Bambale J. A., 2016, The Effect of Brand Name on Consumer Purchase Intention in Kano Metropolis: A Conceptual Model, International Journal of Management and Commerce Innovation, ISSN 2348-7585(online), Vol. 4, Issue 1 pp (58-63),www.researchpublish.com.

16. Barnes, Stuart and Richard Vidgen, 2006. Data triangulation and web quality metrics: A case study in e-Government. A Journal of Information and Management of ELSEVIER, 0378-7206.

17. Berry, L.L. and Parasuraman, A. (1991), Marketing Service - Competing through Quality, The Free Press, New York, NY. 
18. Barnes, Stuart and Richard Vidgen, 2006. Data triangulation and web quality metrics: A case study in e-Government. A Journal of Information and Management of ELSEVIER, 0378-7206.

19. Barreda, Albert A. , Anil Bigihan, Khaldoon Nusair, and Fevzi Okumus, 2015. Generating brand awareness in Online Social Networks. Journal of Elsevier, 07475632.

20. Barwise, P. And Meehan. S., 2010. The One Thing You Must Get Right When Building A Brand, Harvard Business Review, 88 (12), 80-84.

21. Berry, L. (1983), Relationship Marketing. Emerging Perspectives on Service Marketing Chicago:AMA.

22. Bharati, Pratyush and Abhijit Chaudhury, 2004. An Empirical Investigation of DecisionMaking Satisfaction in Web-Based Decision Support Systems. 187-197.

23. Chen, Jennifer , 2009. The Impact of Aesthetics on Attitudes Towards Website. An Article of usability.gov .

24. Chang K.C., Kuo N.T., Hsu C.L., Chen Y.S., 2014, The Impact of Website Quality and Perceived Trust on Customer Purchase Intention in The Hotel Sector: Website Brand and Perceived Value as Moderators, International Journal of Innovation Management and Tecnology, Vo. 5 No. 4.

25. Choe P., and Zhao Y., The Influence of Airline Brand on purchase Intention of Air Tikcets in China, 2013, Industrial Engineering \& Management System, Vol.12, No. 2, $P(143-150)$, ISSN: 1598-7248, EISSN: 2234-6473.

26. Cho E. and Kim K. Y., 2012, The Effect of Website Designs, Self-Congruity, and Flow on Behavioral Intention, 2012, International Journal of Design, Vol. 6 No. 2, p 31-39.

27. Cobb-Walgren, C.J., Ruble, C.A. and Donthu, N.,1995. Brand Equity, Brand Preference, and Purchase Intention, Journal of Advertising, 24 (3), 25-40.

28. Caceres, R. C. and Paparoidamis, N.G., (2007). Service quality, Relationship satisfaction, Trust, Commitment and Business-to-Business Loyalty. European Journal of Marketing, 41 (7/8), pp 836-867.

29. CvijikJ, Irena Pletikosa, Goekmen Cetin, Stephan Karpischek, and Florian Michahelles, 2010. Influence of Facebook on Purchase Desicion Making, Department of Management, Tecnology and Economic, ETH Zurich, Switzerland.

30. Cyr,D.Bonami,C.,Bowes,J., and Ilsever J, 2005. Beyond Trust Website Design Preference A Cross Culture, Journal of Global Information Management, 13(4), 24-25.

31. Chi H.K., yeh H.R., Chien S., Yang Y.T., 2009, The Impact of Brand Awraeness on Consumer Purchase Intention: The Mediating Effect of Perceived Quality and Brand Loyalty, The Journal of Interntional Management Studies, Vol. 4, No. 1.

32. Dolak, Dave. 2005. Building A Strong Brand: Brand and Branding Basics. www.davedolak.com.

Durianto, Darmadi; Sugiarto; Lie Joko Budiman. 2004. Brand Equity Ten: Strategi Memimpin Pasar. Jakarta : Gramedia Pustaka Utama.

33. D. Sirdeshmukh, J. Singh, and B. Sabol, "Consumer Trust, Value, and Loyalty in Relational Exchanges," Journal of Marketing, vol. 66, no. 1, pp. 15-37, Jan. 2002.

34. Durianto, Darmadi; Sugiarto; Tony Sitinjak. 2001. Strategi Menaklukkan Pasar Melalui Riset Ekuitas and Perilaku Merek. Jakarta : Gramedia Pustaka Utama.

35. Ertemel V. A. and Ammoura A., 2016, The Role of social Media Advertisinf in Consumer Buying Behaviour, International Journal of Commerce and Finance, Vol. 2, Issue 1, p. 81-89.

36. Ekhveh A. and Darvishi Z.A., 2015, The Impact of Brand Awareness on Re-purchase Intention of Customer With Trilogy of Emotion Approach (Case Study for Cell Phones), Applied Mathematics in Engineering Management and Tecnology 3 (4), P (25-30), www.amiemt-journal.com.

Farooq, Faraz and Zohaib Jan, 2012 . The Impact of Social Networking To Influence Marketing Through Product Reviews. International Journal of Information and Communication Technology Research, 2223-4985

37. Fromm, Jeff and Christie Garton, 2013 . Marketing to Millenials. USA, Amacom 
38. Fahy, J., \& Smithee, A. (1999). Strategic marketing and the resource based view of the firm. Retrieved Feb, 5, 2007, from http://www.amsreview.org/articles/fahy 10-1999.pdf Ford, D., Gadde, L.-E., Hakansson, H., Lundgren, A., Snehota, I., Turnbull, P., et al. (1998). Managing Business Relationships: West Sussex, England: John Wiley \& Sons Ltd.

39. Gaber, Hazem Rasheed and Len Tiu Wright, 2014. Fast-food advertising in social media. A case study on Facebook in Egypt. Journal of Business and Retail Management Research, Vol.9 Issue 1.

40. Ghani Noor Hasmini Abd. DR, Relationship Marketing In Branding: The Automobile Authorized Independent Dealers In Malaysia, International Journal of Business and Social Science Vol. 3 No. 5; March 2012.

41. Griffin, Jill (2003), Customer Loyalty : Menumbuhkan and Mempertahankan Kesestiaan Pelanggan, terjemahan oleh Dwi Kartini Y., 2009, Jakarta, Erlangga.

42. Goshali, Imam, 2011, Aplikasi Analisis Multivariat Dengan Program SPSS, Baand Penerbit Universitas Diponegoro, Semarang

43. Ganguly B, Dash B.S., Cyr D., Head M., 2010, The Effects of Website Design on Purchase Intention in Online Shopping: The Mediating Role of Trust and The Moderating Role Culture, International Jounal Electronic Business, Vol. 8, No. 4/5.

44. Gholami S, 2017, The Impact of Customer Realtionship on Brand Equity, International Journal of Applied Business and Economic Research, ISSN: 0972-7302, Vol 15, No. 5, www.serialsjournals.com.

Godey B., Manthiou A., Pederzoli D., Rokka J., Aiello G., Donvito R., Singh R., 2016, Social Media Marketing Efforts of Luxury Brands: Influence on Brand Equity and Consumer Behaviour, Journal of Business Research XXX-XXX, http://dx.doi.org/10.1016/j.jbusres,2016.04.181.

Gaurav K., 2016, Impact of Relationship Marketing on Customer Loyalty: Evidance from Indian Automobile Industry, Associate Deab (Strategic Research), IBM-School of Business Excellence, hyderabad, India, Vol IX, No.1.

45. H. Abu-Rumman and Anas Y. Alhadid, 2004. The Impact of Social Media Marketing on Brand Equity: An Empirical Study on Mobile Service Providers in Jordan. Review of Intergrative Business and Economics Research, 2304-1269

46. Hair, J.F., Black, W.C., Babin, B.J., Anderson, R.E., and Tatham, R. L. (2009). Multivariat Data Analysis Sixth Edition. New Jersey : Peasrson Prentice Hall.

47. Hayta, Ates Bayazit, 2013, A study on the effect of social media on young consumer's buying behaviors. European Journal of Research on Education, 2147-6284.

48. Hyejeong Kim and Linda S. Niehm. 2009, The Impact Of Website Quality On Information Quality, Value, And Loyalty Intentions In Apparel Retailing. Journal Of Interactive Marketing, 23: 221133.

49. Hausman A.U., Siekpe J.S., 2008, The Effect of Web Interface Features on Consumer Online Purchase Intentions, Journal of business Research, P (5-13),Elsevier Inc., www.sciencedirect.com.

Jiang, Ling Alice, Zhilin Yang, and Minjoon Jun, 2013, Measuring consumer pereceptions of online shopping conveniece. Journal of Service Management, Vol. 24 No. 2 1757-5818. www. emeraldinsight.com.

50. Jiang Z., Chan J., Tan B.C.Y., Chua W.S., 2010, Effects of Interactivity on Website Involvement and Purchase Intention, Journal of the Association for information System, Vol. 11 Issue 1 pp.34-59.

51. Jeng Shih-Peng, 2016, The influence of Airlines Brand Credibility on Consumer Purchase Intentions, Journal on Air Transport Management 55, P (1-8), www. Elsevier.com/locate/jairtraman.

52. Jezri P., Ahmadi f., Fatehipoor M., 2013, Effects of Relationship Marketing on Customer Loyalty (Case Study: Mehr bank, Kermanshah Province. Iran),Interdisciplinary journal of Contemporary Research in Business, Vol. 4, No. 11, ijcrb.webs.com. 
53. Kaplan, A.M and Haenlein,M.,2010, Users Of The World, United The Challenges and Opportunities Of Social Media Business, Horizon, 53, 59-68.

54. Keller, K.L. (2008). Strategic brand management (3rd ed.). Upper Saddle River, N.J.: Pearson Prentice Hall.

55. K. M. Chu, "The Construction Model of Customer Trust, Perceived Value and Customer Loyalty," The Journal of American Academy of Business, Cambridge, vol. 14, no. 2, pp. 98-103, Mar. 2009.

56. Keller.,K.,L., 1993, Conceptualizing Measuring And Managing Customer Based Brand Equity The Journal Of Marketing 57 (January), 1-22

57. Keller, K, L. (2013). Strategic Brand Management: Building, Measuring, and Managing Brand Equity. 4th ed. England:Pearson Education Limited

58. Khatib, Fahed, 2016. The Impact of Social Media Characteristics on Purchase Desicion Empirical Study of Saudi Customers in Aseer Region. International Journal of Business and Social Science Vol. 7 No. 4.

59. Kosarizdeh, Mohammad and Karin Hamdi, 2015 . Studying the Effect of Social Media on Comsumer Purchase Intention (Case Study: Leather Products). Journal of Applied Environmental and Biological Sciences 2090-4274.

60. Kotler, P., Keller, K.L. 2012. Marketing management (14th ed.). Upper Saddle River, N.J.: Pearson Prentice Hall.

61. Kumar, Prasmana, Venkateswara Raju, 2013. The Role of Advertising in Consumer Desicion Making. IOS Journal of Business and Management.

62. Lee, MKO and Turban E, 2001. Atrust Model For Consumer Internet Shopping , International Journal Elektronic Commerce, 75-91

63. Loanas, Elizabeth and Ivona Stoica, 2014. Social Media and its Impact on Consumer Behavior. International Journal of Economics Practices and Theories, 2247-7225.

64. Leong, E. K. F., Huang, X., \& Stanners, P. J. (1998). Comparing The Effectiveness of The Web Site With Traditional Media. Journal of Advertising Research, 38(5).

65. Lee S. S. H., Khong K.W., Hong J. L., 2014, Influence of Online Shopping Enjoyment and Trust Towards Purchase Intention in Social Commerce Sites, Australian Journal of Basic and Applied Science, 8(8) Spesial, Pages 62-67.

66. Ling K.C., Chai L.T., Piew T.H., The Effect of Shopping Orientations, Online trust and Prior Online Purchase Experience Toward Customers Online Purchase Intention, 2010, International Business Research, Vol. 3, No. 3, wwwccsenet.org/ibr.

67. Moriarty, et al. 2011. Advertising. Jakarta: Kencana

68. Motwani, Dharmesh, Devendra Shrimali, and Khushbu Agarwal, 2014. Customer's Attitude towards Social Media Marketing 2319-5614.

69. Morgan, M and Hunt, S. (1994). The Commitment-Trust Theory of Relationship Marketing. Journal of Marketing, Vol 58., No. 3., July, 1994. Retrieved February 10th 2014.

70. Morrison, G. D. (1979), Purchase Intentions and Purchase Behavior. Journal of Marketing, 43, 65-74.

71. Mohammed Alireza A., Arbatni T.R., Gholipour T.H., Farzianpour F., Hosseini S., 2014, A Survey on The Effect of Social Media Marketing on Online Shopping of Customers by Mediating Variables, Journal of Service Science and Management, 7, P ( 368-376), http://www.scirp.org.

Motwani D., Shrimali D., Agarwal k., 2014, Customers Attitude Towards Social Media marketing, Journal of Business Management \& Social Science Research (JBM\&SSR), ISSN No: 2319=5614, Vol 3, No.4, www.borjournals.com

Mekala A. and Vennila A, 2017, Iternet Marketing to Improve Brand Awareness, International Journal of Commerce and Management Research, ISSN: 2455-1627, Vol 3, Issue 3, P (89-91), www. Managejournal.com

72. McMillan S.J., 2004, Internet Advertising:One Face or Many, Theory and Research (2nd edition), University of Tennessee, Knoxville, TN.

73. Ndubisi, N.O. and Wah C.K. (2005). Relationship marketing and customer loyalty. Journal of Marketing Practice: Applied Marketing Science, 25(1), 98-106. 
74. Newman, David, 2013. Do It! Marketing. 0-8144-3286-7.

75. Paquette, Holly, 201. Social Media as a Marketing Tool: A Literature Review. Major Papers by Master of Science Students Paper 2 .

76. Nelson Ndubisi and Chan Kok Wah from Griffith University, Australia. Their research paper was published on Marketing Intelligence \& Planning, Vol. 25 Iss: 1, pp.98 - 106 (2005)

77. Pulizzi, Joe, 2014. Epic Content Marketing. 978-0-07-181989-3.

78. Rangkuti, Freddy. 2002. Teknik Mengelola Brand Equity And Strategi Pengembangan Merek. Jakarta : Gramedia Pustaka Utama

79. Rangkuti, fredy, 2005. Riset Pemasaran, Elexmedia Computindo, Jakarta

80. Rizwan M., Qayyun M., Qaderr W., Javed M., 2014, The Impact on Branded Product on Cunsumer Purchase Intention, Journal of Public Administration and Governance, ISSN: 2161-7104, Vol.4 No. 3, www.macrothink.org/jpag.

Rehman, Fazal ur Muhammad, Tariq Nawaz, Khan Aminullah, and Shabir Hyder, 2014. How Advertising Affects the Buying Behavior of Consumers in Rural Areas: A Case of Pakistan. Academic Research International, 2223-994.

81. Rumman-Abu A.H., Alhadid a.y, 2014, The Impact of Social Media Marketing on Brand Equity: An Empirical Study on Mobile Service Provider in Jordan, Society of Interdisciplinary Business Research, Vo; 3(1), ISSN; 2304-1013 (Online): 2304-1269, www.sibresearch.org.

Rowles, Daniel, 2014. Digital Branding. London, New Delhi, Philadelphia, Kogan Page.

82. Saaksjarvi, Maria and Saeed Samiee, 2011. Relationships among Brand Identity, Brand Image and Brand Preference: Differences between Cyber and Extension Retail Brands over Time. Journal of Interactive Marketing, 1094-9968.

83. Sanusi, Anwar, 2011. Metodologi Penelitian Bisnis. Buku Tentang Metodologi Penelitian Bisnis, Jakarta, Salemba Empat

84. Schiffman, L.G., Kanuk, LL, 2007. Consumer Behaviour, ninth ed. Prentice-Hall Inc, NJ.

85. Sharma A., and Arora S., 2013, Social Media:A Successful Tool of Brand Awareness, InternationalAcademy of Science Engineering and Tecnology, ISSN:23192267, Vol2Issue 3

86. Spears, N. and Singh, S. N. (2004), Measuring Attitude Toward the Brand and Purchase Intentions, Journal of Current Issues and Research in Advertising, 26(2), 5466.

87. Smith, M.D. Brynjolfsson, E. (2001), Consumer Decision-making at an Internet Shopbot.

88. Shehzad, U., et „al (2014), Influence of Brand Name on Consumer Choice \& Decision. Journal of Business and Management, 16(6), 72-76.

89. Senecal, Sylvain and Jaques Nantel, 2000. The Influence of online product recommendations on consumers' online choices. Journal of Retailing of Elsevier, 159169.

90. Seth, Swati and Komal Kapoor, 2014. Fostering Creativity and Innovation In Marketing Communication through Social Media. The International Journal of Business and Management, 2321-8916.

91. Shergill, Gurvinder and Zhaobin Chen, 2005. Web-Based Shopping: Consumers' Attitudes Towards Online Shopping in New Zealand. Journal of Electronic Commerce Research Vol. 6 No. 2.

92. Supranto, J. and Nanand Limakrisna, 2013. Petunjuk Praktis Penelitian IImiah Untuk Menyusun Skripsi, Tesis, and Desertasi. 978-602-1521-43-4.

93. Stock, R.M. 2005. Can customer satisfaction decrease price sensitivity in business-tobusiness markets, Journal of Business-to-Business Marketing, 12(3), pp 59-87

94. Sam M.F.M., Tahir H.N.M., 2017, Website Quality And Consumer Online Puchase Intention Of Air Ticket, International Journal of Basic \& Applied Science IJBAS, Vol: 9 No.10. 
95. Song P., Xu H., Techatassanassoontorn A., Zhang C., 2011, The Influence of Product Integration on online Advertising Effectiveness, Electronic Commerce Research and Applictions 10, p 288-303, www. Elsevier.com.

96. Srinivasan R., Bajaj R., Bhanot S., 2016, Impact of Social Media Marketing Strategies used by Micro Small and Medium Enterprise (MSMEs) on Consumer acquisition and retention, elSSN:2278-487X,p-ISSN:2319=7668, Vol 18, Issue 1 Ver III, P (91-101), www.iosrkournals.org.

Tsang, Melody M., Shu-Chun Ho, and Ting-Peng Liang, 2004. Consumer Attitude Toward Mobile Advertising: An Empirical Study. International Journal of Electronic Commerce 1086-4415.

97. Tulgan, Bruce, 2009. Not Everyone Gets A Trophy: How To Manage Generation Y. 978-0-470-25626-8.

98. Tan, H. and Guo, J. (2005) 'Some methods to depress the risks of the online transactions', ICEC'05, 15-17 August, Xi'an, China.

99. Tarokh M.J., Sheykhan A., 2015, Recognizing Relationship Marketing Dimensions and Effects on Customer Satisfaction, Loyalty and Word of Mounth Advertisement, MAGNT Research Report, ISSN. 1444-8939, Vol.3 (\$),PP:62-86.

100. Tavor T., 2011, Online Advertising Development and Their Economic Effectiveness, Australian Journal of Business and Management Researc Vo.1,No 6

101. Ukkwatte JL and Abeysekera N, 2015, The Impact of Realtionship Marketing on Brand Equity with Special Reference to Cinnamon Red Hotel in Sri Lanka, International Research Conference, KDU, P(152-160)

102. Verma Varsha, Sharma D., Sheth Jagdish, 2015, Does Relationship Marketing Matter in Online Retailing? A meta-anaytic approach, J.pf the Acad.Mark.Sci, DOI 10.1007/s11747-015-0429-6.

103. Wang, Xuehua, Cheris W.C. Chow, and Zhilin Yang, 2012 . A two path model on the effects of positivity and empathy reflected by online reviews: a choice mechanism perspective. International Journal of Internet Marketing and Advertising Vol. 7, No. 3.

104. Wang, Xuehua, Wing Chi Chow, Zhilin Yang, and Jennifer Y.M. Lai, 2014. Market signals: web site investment and physical store exsistence. Asia Pacific Journal of Marketing and Logistics, 1355-5855.

105. WSI, 2013 . Digital Minds, 12 Things Every Business Need to Know About Digital Marketing. 978-1-4602-3019-0.

106. Yang, Zhilin, Shaohan Cai, Zheng Zou, and Nan Zhou, 2005 . Development and validation of an instrument to measuer user perceived service quality of information presenting Web portals. Journal of Information and Management of Elsevier, 575-589.

107. Yaseen N., Tahira M., Gulzar A., Anwar A., 2011, Impact of Brand Awareness, Perceived Quality and Consumer Loyalty on Brand Profitability and Purchase: A Resselers' View, Interdiciplinary Journal of Conteporary Research in Business, Vol. 3 No. 8, ijcrb.webs.com., p 823-839.

108. Yogesh F., Yesha M., 2014, Effect of Social Media on Puchase Decision, Pacific Business Review International, Volume 6, Issue 11.

109. Yu ,Tsu-Wei., Feng-Cheng Tung, 2013, Investigating Effects of Relationship Marketing Types in Life Insurers in Taiwan, Managing Service Quality, Vol. 23 No. 2, pp. 111-113

110. Zviran, Moshe, Chanan Gleser, and Itay Avni, 2005 . User satisfaction from commercial web sites: The effect of design and use. Journal of Information and Management of Elsevier 0378-7206. 